\title{
MODELLING AND SIMULATION OF POUCH LITHIUM-ION BATTERY THERMAL MANAGEMENT USING COLD PLATE
}

\author{
Zhang, X.*; Wang, T. ; Jiang, S. B., ; Xu, H. G. ${ }^{* *} \&$ Zhang, Y. N. ${ }^{* * *}$ \\ * Key Laboratory of Mining Machinery Engineering of Shandong Province, Qingdao 266500, China \\ ${ }^{* *}$ Shandong Shifeng (Group) Co., Ltd., Liaocheng 252899, China \\ *** Faculty of Mechanical Engineering, Czech Technical University in Prague, Prague 6, 16000, \\ Czech Republic \\ E-Mail: jiangshoubo@gmail.com ( ${ }^{\#}$ Corresponding author)
}

\begin{abstract}
The thermal management system is an integral part of a battery pack because of the temperature sensitivity of lithium-ion batteries. Cold plate cooling is a relatively mature liquid cooling method for lithium-ion batteries, but cold plate has a low cooling efficiency and poor economy. To improve the efficiency and economy of cold plate cooling, the effects of inlet mass flow rate and mini-channel cross-sectional width on the maximum temperature, temperature difference, and pressure drop at $4 \mathrm{C}$ discharge rate were analysed. The finite element model of the cold plate cooling system was established by adopting the finite element method. FLUENT was utilized to calculate the cold plate cooling system model, and the cell temperature and mini-channel pressure drop data were obtained. Results show that increasing the mass flow rate of the coolant can reduce the maximum temperature and temperature difference of the cells, but the economy of the cooling system worsens when the mass flow rate exceeds $0.003 \mathrm{~kg} / \mathrm{s}$. In addition, the temperature trend over time presents a typical inverted U-shape with the change in the mini-channel cross-sectional width. Energy consumption and cooling system volume should be reduced by selecting a suitable mass flow rate and mini-channel crosssectional width. This study provides guidance for the design of the pouch lithium-ion battery cold plate cooling system.

(Received in May 2018, accepted in June 2018. This paper was with the authors 2 weeks for 2 revisions.)
\end{abstract}

Key Words: Modelling and Simulation, Lithium-Ion Battery, Thermal Management, Cold Plate, Mass Flow Rate

\section{INTRODUCTION}

The increasing severity of environmental pollution and energy shortage is a global problem. Developing blade and hybrid electrical vehicles has become one of the most effective ways of solving this problem in various countries $[1,2]$. Lithium-ion battery has become a central component of new energy vehicles because of its high energy density, long service life, low self-discharge rate, and strong adaptability [3, 4].

Pouch lithium-ion batteries have been gradually used in new energy vehicles. However, many problems in their safety and life span remain. First, when using the pouch lithium-ion battery, particularly in cases of high-rate discharge, serious heat generation may occur. The pouch lithium-ion battery expands due to overheating when the heat is not drained in time. In severe cases, the lithium-ion battery even burns and explodes [5]. Therefore, a thermal management system of pouch lithium-ion batteries, which ensures that the working temperature of the batteries is between $25^{\circ} \mathrm{C}$ and $40^{\circ} \mathrm{C}$, should be employed to improve the safety of batteries [6]. Second, the temperature difference of the cell should be as small as possible, generally controlled within $5^{\circ} \mathrm{C}$. When the temperature difference is extremely large, the consistency between cells will worsen and seriously affect the life of the cell. Therefore, the thermal management system of pouch lithium-ion batteries is of great significance for increasing the life of batteries. As a key system for the pouch lithium-ion battery pack, the thermal management system of the battery pack should have high efficiency 
and robustness [7]. Meanwhile, the high energy consumption problem of the thermal management system should also be solved. Therefore, optimizing the structure and selecting the appropriate boundary conditions are critical to obtaining a highly efficient and economical thermal management system for pouch lithium-ion batteries.

\section{STATE OF THE ART}

According to research by scholars from all over the world, existing battery thermal management methods include air cooling, liquid cooling, phase change material cooling, and heat pipe cooling. Lu et al. [8] studied the effects of forced air cooling on the temperature difference and maximum temperature of battery packs. However, disadvantages, such as small heat capacity and low thermal conductivity, hinder the air-cooling method from meeting the heat dissipation requirements of large-capacity battery packs. Zou et al. [9] studied the application of various phase change materials in the thermal management of power lithiumion batteries. The ratio of phase change materials was optimized by experiments. Adding phase change materials can improve the temperature balance in the battery pack, but as the heat of the battery is continuously released, the phase change material can only absorb and cannot transfer heat. Greco et al. [10] developed a simplified 1D transient numerical model for prismatic lithium-ion cells to predict the temperature distribution of lithium-ion batteries for thermal management using heat pipes. Rao et al. [11] designed an oscillating heat pipe battery thermal management system and verified its effects by experiments. Although heat pipes have high heat dissipation efficiency, they have high requirements for installation position, and their effects are affected by local gravity.

Compared with the thermal management method, liquid cooling has advantages, such as compact structure, large heat capacity of the coolant, and high thermal conductivity, that result in a good development prospect. In the liquid cooling method, the heat of lithium-ion cells is transferred through the metal plate to the coolant in the mini-channels of the cold plate, and the heat is taken away by the coolant [12]. Chen et al. [13] studied four cooling methods for lithium-ion batteries, namely, air cooling, direct liquid cooling, indirect liquid cooling, and fin cooling. Their results indicated that indirect liquid cooling has a better cooling efficiency than the other cooling methods. Qian et al. [14] studied the impacts of the number of channels, inlet mass flow rates, flow directions, and width of channels on the cooling effects of a typical mini-channel cold plate in a battery pack. Their conclusions suggested that the mini-channel cold plate can efficiently dissipate the heat of lithium-ion batteries with high-rate charge/discharge. However, only the effects of each factor were considered, and the pressure drop of the cooling plate in the cooling system was ignored. Jarrett and Kim [15] optimized the design of the cold plate in different boundary conditions. The cooling effects of cold plate were measured in terms of temperature uniformity, temperature difference, and pressure drop. Panchal et al. [16, 17] established a mini-channel cold plate numerical model for water-cooled lithium-ion batteries by using FLUENT and studied the temperature of the mini-channel cold plate and flow velocity distribution of the coolant. Combined experiments and simulations were used to compare the temperatures under different battery discharge rates and different initial temperatures of the coolant. In the study, the effects of the mini-channel cross-sectional width on battery temperature changes and cold plate pressure drop were not considered. Huo et al. [18] investigated the effects of direct channel cold plates on the thermal dissipation of lithium-ion batteries and analysed the effects of the number of channels, flow directions, mass flow rates, and ambient temperature. However, the change in cold plate pressure drop under the effects of inlet mass flow rate and mini-channel cross-sectional width was ignored. Jin et al. [19] creatively designed a simple configuration of oblique cuts across the straight fins of a conventional straight channel. This 
design reduces the pressure drop of the mini-channel compared with those of traditional flow channels. The results of their experiment proved that their proposed design exhibits better heat dissipation effects than traditional channels. Wang et al. [12] first used thermal silica plates to cool prismatic lithium-ion batteries and studied the cooling effects of different numbers of cooling channels, flow rates, and flow directions on lithium-ion batteries with different discharge rates.

Various methods of lithium-ion battery thermal management have been studied, and the cold plate cooling method demonstrates numerous practical application prospects. The main research contents of the existing literature on cold plate cooling methods include the effects of inlet mass flow rate, flow direction, channel width, and external environment on the maximum temperature and temperature difference of batteries. However, as a key part of the cooling system, the effects of various factors on the pressure drop of the mini-channel were seldom studied. Therefore, on the basis of the existing cold plate design, the effects of inlet mass flow rate and mini-channel cross-sectional width on the heat dissipation of lithium-ion batteries are analysed in this study, and the cooling effects are measured by the maximum temperature and temperature difference of lithium-ion batteries. In addition, the effects of inlet mass flow rate and mini-channel cross-sectional width on the pressure drop of the cold plate mini-channel are considered. The results of this research provide guidance to the design of a cold plate cooling system.

The rest of this study is organized as follows. Section 3 introduces the cold plate cooling system's physical model in detail, presents the grid model, and provides the specific setting of the numerical calculation software FLUENT 17.0. Section 4 analyses the results of the numerical calculation, namely, the effects of inlet mass flow rate and mini-channel crosssectional width on the maximum temperature and temperature difference of lithium-ion batteries and on the pressure drop of the cold plate mini-channel. Section 5 presents a summary of the conclusions.

\section{METHODOLOGY}

\subsection{Cold plate cooling system physical modelling}

Fig. 1 a presents a schematic of the pouch lithium-ion cell cooling system model. A cold plate is placed between two cells to form a sandwich structure. The coolant enters from the inlet and flows out from the outlet of the cold plate. The cells used in this cooling system are commercial lithium-ion batteries from a Chinese manufacturer, with a capacity of $22 \mathrm{Ah}$. The pouch lithium-ion battery model is appropriately simplified, leaving only the body of the cell. The cell body is $155 \mathrm{~mm}$ in length, $8.7 \mathrm{~mm}$ in width, and $235 \mathrm{~mm}$ in height.

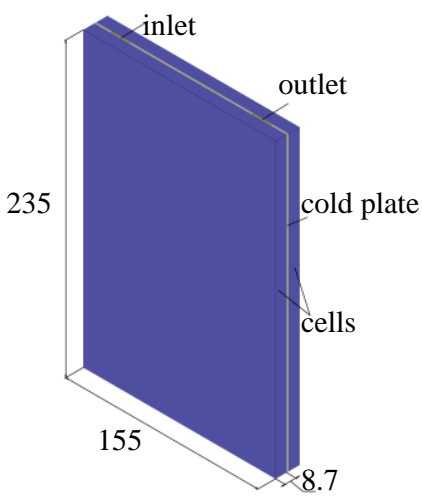

a)

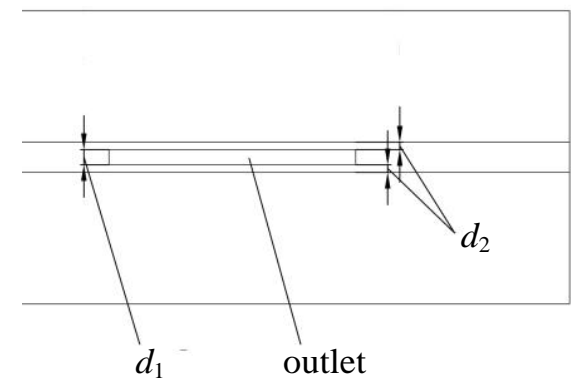

b)

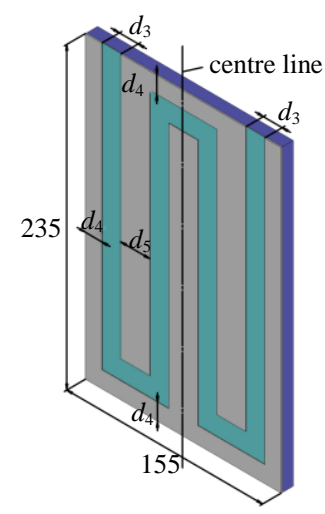

c)

Figure 1: Schematics of the cooling system model. 
Figs. $1 \mathrm{~b}$ and $1 \mathrm{c}$ show the schematics of the cold plate model. The mini-channel in the cold plate is of equal section, where $d_{1}$ is the mini-channel cross-sectional width, $d_{2}$ is the thickness between the side of the mini-channel parallel to the long side of the cell and the interface between the cold plate and cell, $d_{3}$ is the cross-sectional length of the mini-channel, $d_{4}$ is the length from mini-channel to the cold plate side, and $d_{5}$ is the distance between the different sides of the mini-channels within the cold plate. An ethylene glycol aqueous solution $(50 \% \mathrm{EGW})$ was used as a coolant. Table I shows the sizes of the cold plate.

Table I: Sizes of the cold plate.

\begin{tabular}{|c|c|c|c|c|c|}
\cline { 2 - 6 } \multicolumn{1}{c|}{} & $\boldsymbol{d}_{\mathbf{1}}$ & $\boldsymbol{d}_{\mathbf{2}}$ & $\boldsymbol{d}_{\mathbf{3}}$ & $\boldsymbol{d}_{\mathbf{4}}$ & $\boldsymbol{d}_{\mathbf{5}}$ \\
\hline Unit: $\mathrm{mm}$ & $1 / 1.5 / 2 / 2.5 / 3$ & 0.5 & 15 & 13 & 23 \\
\hline
\end{tabular}

\subsection{Cold plate cooling system numerical solution}

The 3D model was divided into hexahedral meshes by using ICEM CFD 17.0. To ensure the accuracy of simulation results, a grid independence test was performed. Given that the model was divided into hexahedral meshes, the number of meshes had less influence on the calculation results. The result of the grid independence test is shown in Fig. 2. Considering the result of the grid independence test and the computational performance of the computer, the number of grids for the five models was controlled between 3 and 3.5 million.

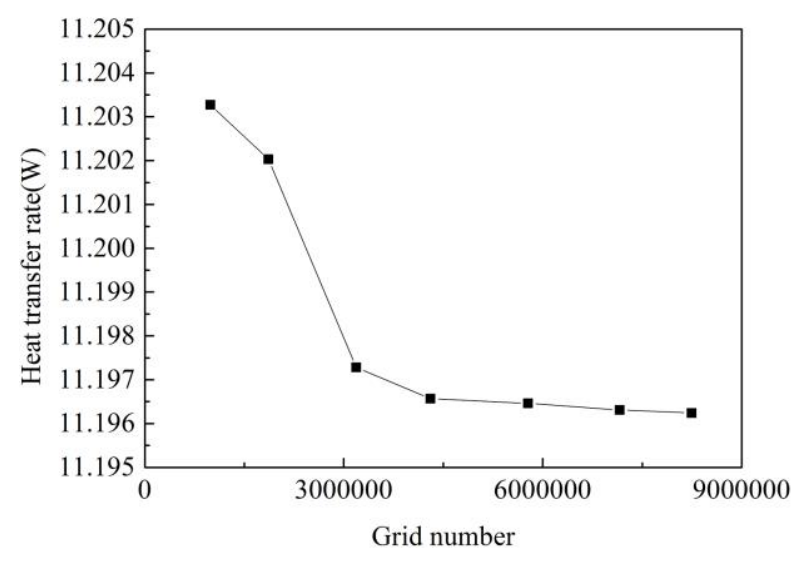

Figure 2: Independent test of grid number.

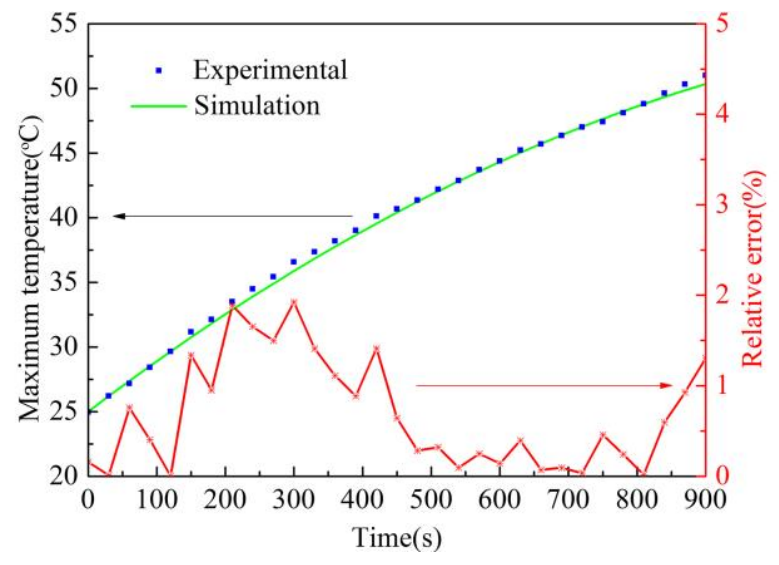

Figure 3: Comparison of cell $4 \mathrm{C}$ discharge rate heating simulation and experiment.

Table II: Thermal properties of materials.

\begin{tabular}{|l|c|c|c|c|}
\hline \multicolumn{1}{|c|}{ Material } & $\begin{array}{c}\text { Density } \\
\left(\mathrm{kg} \cdot \mathrm{m}^{-3}\right)\end{array}$ & $\begin{array}{c}\text { Heat capacity } \\
\left(\mathrm{J} \cdot \mathrm{kg}^{-1} \cdot \mathrm{K}^{-1}\right)\end{array}$ & $\begin{array}{c}\text { Heat transfer } \\
\text { coefficient } \\
\left(\mathrm{W} \cdot \mathrm{m}^{-1} \cdot \mathrm{K}^{-1}\right)\end{array}$ & $\begin{array}{c}\text { Dynamic } \\
\text { viscosity } \\
(\mathrm{Pa} \cdot \mathrm{s})\end{array}$ \\
\hline $50 \%$ EGW & 1071.11 & 3300 & 0.384 & 0.00339 \\
\hline Battery & 1924.9 & 1210 & $0.9 / 2.7 / 2.7$ & - \\
\hline Aluminium & 2719 & 871 & 202.4 & - \\
\hline Al-Plastic Film & 1390 & 460 & 66.6 & - \\
\hline
\end{tabular}

FLUENT 17.0 was used to solve the heat model in this study. The Reynolds numbers of all the models were less than 2300 by calculation, so the laminar model was chosen. The mass-flow-inlet was selected for the mini-channel inlet boundary conditions; the mass flow rates of the coolant were $0.001,0.002,0.003,0.004$ and $0.005 \mathrm{~kg} / \mathrm{s}$; and the initial temperature of the coolant was set to $25^{\circ} \mathrm{C}$. The outlet boundary condition was defined as the pressure outlet. The cells and cold plate were set based on the surface in contact with air to the convection thermal condition, and the heat transfer coefficient and free stream temperature 
were set to $5 \mathrm{~W} /(\mathrm{m} \cdot \mathrm{K})$ and $25^{\circ} \mathrm{C}$, respectively. Table II shows the thermal properties of the materials used in the numerical calculations. The cells were operated at $4 \mathrm{C}$ discharge rate and a discharge time of $900 \mathrm{~s}$. The heat source was defined by using the user-defined function in FLUENT [20]. The comparison of cell $4 \mathrm{C}$ discharge rate heating simulation and experiment is shown in Fig. 3. The figure shows that the relative error does not exceed $2 \%$.

\section{RESULT ANALYSIS AND DISCUSSION}

In this study, $\Delta T$ presents the temperature difference of cells. Twenty-five numerical calculations were carried out by changing the mass flow rate of the coolant and crosssectional width of the mini-channel.

The temperature difference was obtained by subtracting the minimum temperature from the maximum temperature of the cell extracted from the calculation result, and the pressure drop was obtained by subtracting the maximum pressure of the mini-channel outlet from that of the inlet. Subsequently, the effects of coolant mass flow rates and the mini-channel crosssectional width on the maximum temperature and temperature difference of the cells were analysed. The effects of the mass flow rate and the mini-channel cross-sectional width on pressure drop were also studied.

Fig. 4 shows the temperature contours under different $d_{1}$ values and mass flow rates at the time when the maximum temperature reaches the maximum value in the five sets of numerical calculation data. Taking the centre of the cooling system model as the origin, the cell on the left side of the cooling system model is sliced at $Y=0 \mathrm{~mm}$ and $Y= \pm 57 \mathrm{~mm}$ to show the temperature distribution inside the cell. As shown in Fig. 4, the temperature of the cell gradually increases along the flow path of the coolant. In the X-axis direction, the temperature increases with the distance from the cold plate. In summary, the minimum temperature zone on the cell approaches the mini-channel inlet, and the maximum temperature zone on the cell is on the cell edge that is far from the mini-channel outlet.

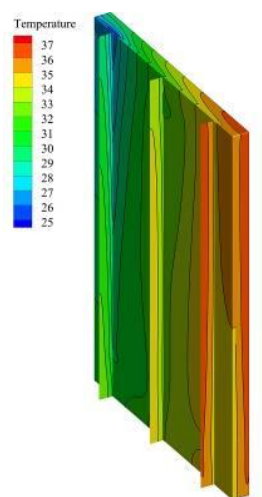

a) $d_{1}=1 \mathrm{~mm}$

$t=660 \mathrm{~s}$

$0.001 \mathrm{~kg} / \mathrm{s}$

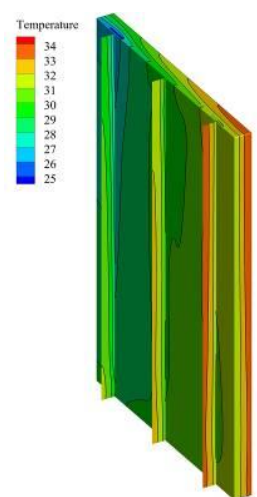

b) $d_{1}=1.5 \mathrm{~mm}$

$t=540 \mathrm{~s}$

$0.002 \mathrm{~kg} / \mathrm{s}$

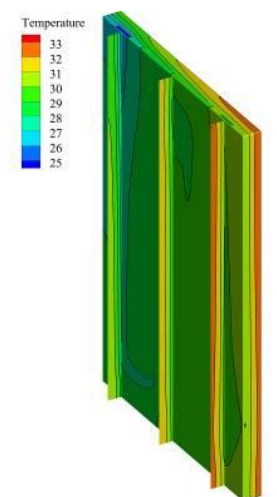

c) $d_{1}=2 \mathrm{~mm}$ $t=480 \mathrm{~s}$

$0.003 \mathrm{~kg} / \mathrm{s}$

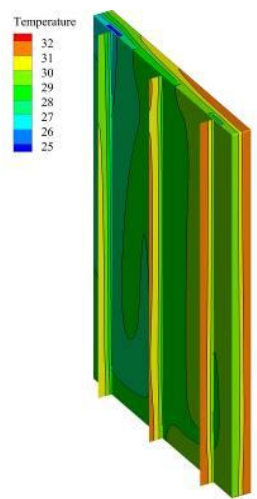

d) $d_{1}=2.5 \mathrm{~mm}$ $t=450 \mathrm{~s}$ $0.004 \mathrm{~kg} / \mathrm{s}$

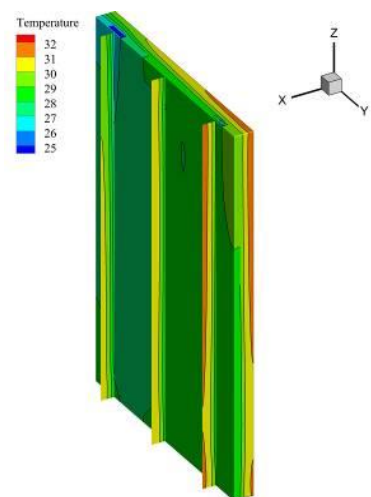

e) $d_{1}=3 \mathrm{~mm}$

$t=450 \mathrm{~s}$

$0.005 \mathrm{~kg} / \mathrm{s}$

Figure 4: Temperature contours under different $d_{1}$ values and mass flow rates $(0.001 \ldots 0.005 \mathrm{~kg} / \mathrm{s})$.

\subsection{Effects of mass flow rates on maximum temperature}

We then take the model with $d_{1}=3 \mathrm{~mm}$ as an example to analyse the numerical calculation results in detail.

Fig. $5 \mathrm{~b}$ shows that the maximum temperature first increases to the maximum value with the discharge time and then decreases, although the mass flow rates are different. This pattern is consistent with the trend of the cells heating to change over time. Fig. 3 shows that the 
simulated temperature curve of the cells increases with time, but the slope of the simulated temperature curve gradually decreases. We can deduce that the heating power of the cell gradually decreases over time. When the heat generated by the cell is the same as the heat removed by the coolant, the maximum temperature of the cell reaches the highest value. The heat generated by the cell is lower than the heat removed by the coolant, and the maximum temperature curves show a decreasing trend. In addition, the maximum temperature growth rate decreases with the increase in the mass flow rate. From the numerical calculation data of the $d_{1}=3 \mathrm{~mm}$ model, when the mass flow rate of the coolant is $0.001 \mathrm{~kg} / \mathrm{s}$ and the discharge time is $720 \mathrm{~s}$, the maximum temperature reaches a maximum value of $36.1{ }^{\circ} \mathrm{C}$; when the mass flow rate of coolant is $0.002 \mathrm{~kg} / \mathrm{s}$ and the discharge time is $570 \mathrm{~s}$, the maximum temperature reaches a maximum value of $33.7^{\circ} \mathrm{C}$; when the mass flow rate of the coolant is $0.003 \mathrm{~kg} / \mathrm{s}$ and the discharge time is $510 \mathrm{~s}$, the maximum temperature reaches a maximum value of $32.7^{\circ} \mathrm{C}$; when the mass flow rate of the coolant is $0.004 \mathrm{~kg} / \mathrm{s}$ and the discharge time is $480 \mathrm{~s}$, the maximum temperature reaches a maximum value of $32{ }^{\circ} \mathrm{C}$; and when the mass flow rate of the coolant is $0.005 \mathrm{~kg} / \mathrm{s}$ and the discharge time is $450 \mathrm{~s}$, the maximum temperature reaches a maximum value of $31.4{ }^{\circ} \mathrm{C}$. The time at which the maximum temperature of the cells reaches its maximum value is gradually advanced with the increasing mass flow rate. As the amount of heat taken away by the coolant increases, the time at which the amount of heat taken by the coolant is equal to the amount of heat generated by the cell is advanced. In addition, the maximum temperature is changed from $36.1{ }^{\circ} \mathrm{C}$ to $33.7^{\circ} \mathrm{C}$ when the mass flow rate changes from $0.001 \mathrm{~kg} / \mathrm{s}$ to $0.002 \mathrm{~kg} / \mathrm{s}$, showing a decrease of $2.4^{\circ} \mathrm{C}$. The maximum temperature changes from $32{ }^{\circ} \mathrm{C}$ to $31.4{ }^{\circ} \mathrm{C}$ when the mass flow rate of the coolant changes from $0.004 \mathrm{~kg} / \mathrm{s}$ to $0.005 \mathrm{~kg} / \mathrm{s}$, showing a decrease of $0.6{ }^{\circ} \mathrm{C}$. These results indicate that the maximum temperature reduction decreases with the increasing mass flow rate of the coolant. Fig. 6 shows that only the coolant velocity in the middle position of the minichannel is multiplied, but the increase in velocity at the edge position is small. Meanwhile, the amount of heat conducted to the coolant is closely related to the velocity at the edge position.

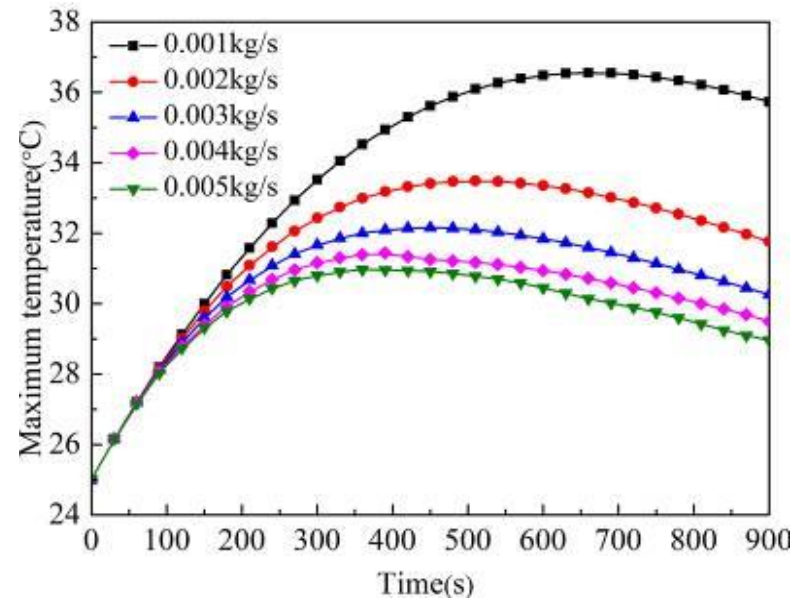

a) $d_{1}=1 \mathrm{~mm}$

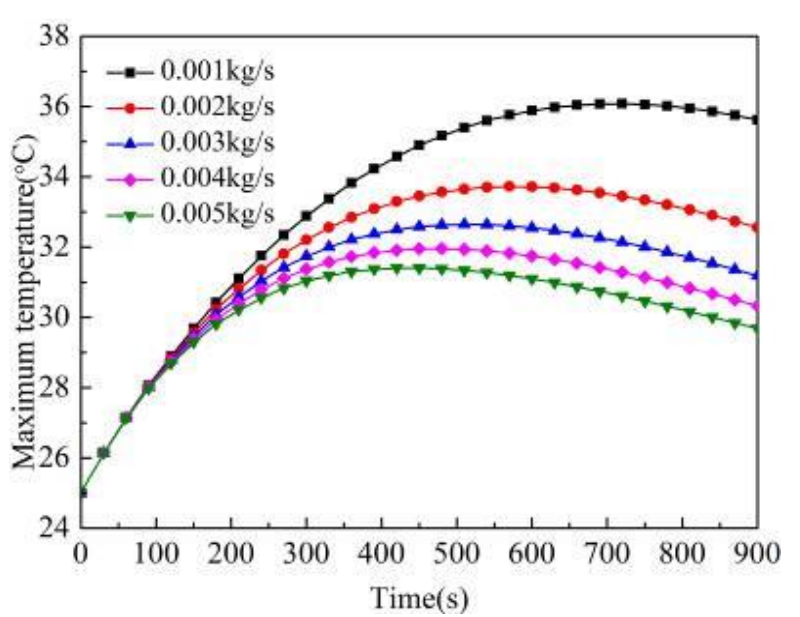

b) $d_{1}=3 \mathrm{~mm}$

Figure 5: Comparison of the cells' maximum temperature under different $d_{1}$ values and mass flow rates.

As shown in Fig. 5 b, in the first $120 \mathrm{~s}$, the different mass flow rates of the coolant have a slight effect on the maximum temperature of the cell, but the maximum temperature increases rapidly. When the discharge time is $120 \mathrm{~s}$, the maximum temperatures at the mass flow rates of 0.005 and $0.001 \mathrm{~kg} / \mathrm{s}$ are $28.7^{\circ} \mathrm{C}$ and $28.9^{\circ} \mathrm{C}$, respectively, with a difference of $0.2^{\circ} \mathrm{C}$. The cell has the highest heat power at the beginning, and the temperature rises quickly. However, the initial temperature difference is small and the heat conduction time is long, so 
the heat taken away by the coolant is limited, and the mass flow rate has a minimal effect on the maximum temperature.

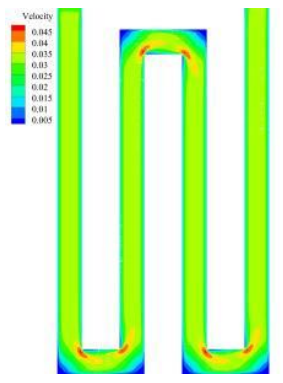

a) $0.001 \mathrm{~kg} / \mathrm{s}$ $t=750 \mathrm{~s}$

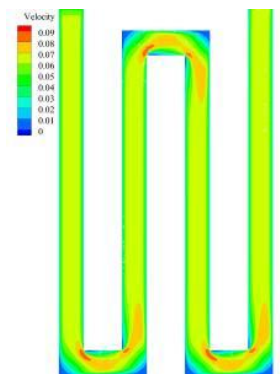

b) $0.002 \mathrm{~kg} / \mathrm{s}$ $t=600 \mathrm{~s}$

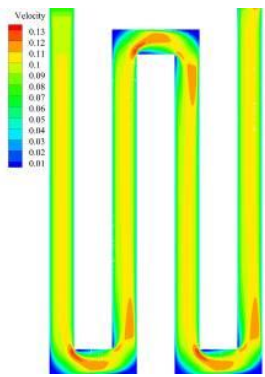

c) $0.003 \mathrm{~kg} / \mathrm{s}$ $t=540 \mathrm{~s}$

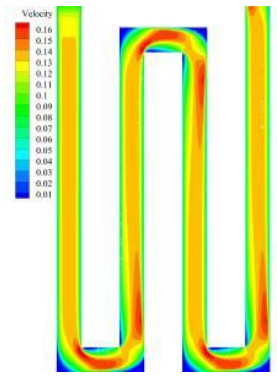

d) $0.004 \mathrm{~kg} / \mathrm{s}$ $t=510 \mathrm{~s}$

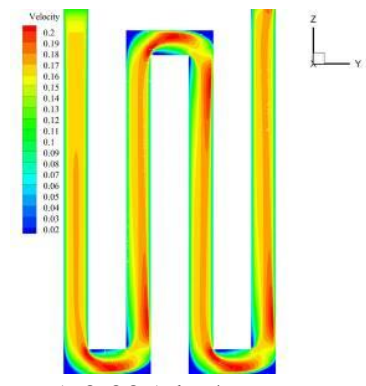

e) $0.005 \mathrm{~kg} / \mathrm{s}$ $t=450 \mathrm{~s}$

Figure 6: Coolant flow velocity in the mini-channel at the maximum temperature difference under different flow rates, $d_{1}=3 \mathrm{~mm}$.

\subsection{Effects of mass flow rates on temperature difference}

As Fig. $7 \mathrm{~b}$ shows, although the mass flow rates of the coolant differ, the temperature difference gradually rises as the discharge time increases. The temperature difference reaches the maximum value, and the temperature difference gradually decreases. The temperature difference trend is affected by the variation in the highest and lowest temperatures. From the numerical calculation data of the $d_{1}=3 \mathrm{~mm}$ cooling system model, when the mass flow rate is $0.001 \mathrm{~kg} / \mathrm{s}$ and the discharge time is $750 \mathrm{~s}$, the maximum temperature difference reaches $8.1{ }^{\circ} \mathrm{C}$; when the mass flow rate is $0.002 \mathrm{~kg} / \mathrm{s}$ and the discharge time is $600 \mathrm{~s}$, the maximum temperature difference reaches $6.6{ }^{\circ} \mathrm{C}$; when the mass flow rate is $0.003 \mathrm{~kg} / \mathrm{s}$ and the discharge time is $540 \mathrm{~s}$, the maximum temperature difference reaches $5.9^{\circ} \mathrm{C}$; when the mass flow rate is $0.004 \mathrm{~kg} / \mathrm{s}$ and the discharge time is $510 \mathrm{~s}$, the maximum temperature difference reaches $5.4{ }^{\circ} \mathrm{C}$; and when the mass flow rate is $0.005 \mathrm{~kg} / \mathrm{s}$ and the discharge time is $450 \mathrm{~s}$, the maximum temperature difference reaches $5{ }^{\circ} \mathrm{C}$. As the mass flow rate increases, the time points to reach the maximum temperature difference are advanced. In addition, the reductions in the temperature difference gradually decrease. Between 180 and $900 \mathrm{~s}$, the changes in the temperature difference curves follow the regulation of the maximum temperature. At 0-180 s, the temperature difference shows a different regulation with the increase in the mass flow rate, that is, the temperature difference increases slightly with increasing mass flow rate. In this time interval, the heating power of the cell is relatively large, resulting in a rapid temperature rise of the cell. The distance from the highest temperature zone of the cell to the cold plate is farther than the distance from the lowest temperature zone to the cold plate, and the heat transfer rate in the high temperature zone is less than that in the low temperature zone. As the mass flow rate of the coolant increases, the amount of heat taken away from the low temperature zone is larger than that from the high temperature zone, resulting in a gradual increase in temperature difference.

The time when the maximum temperature difference occurs is later than the time when the highest value of maximum temperature occurs, because the high temperature zone is farther from the cold plate and the low temperature zone is closer to the cold plate. The decrease rate of temperature in the highest temperature zone is less than that in the lowest temperature zone. 


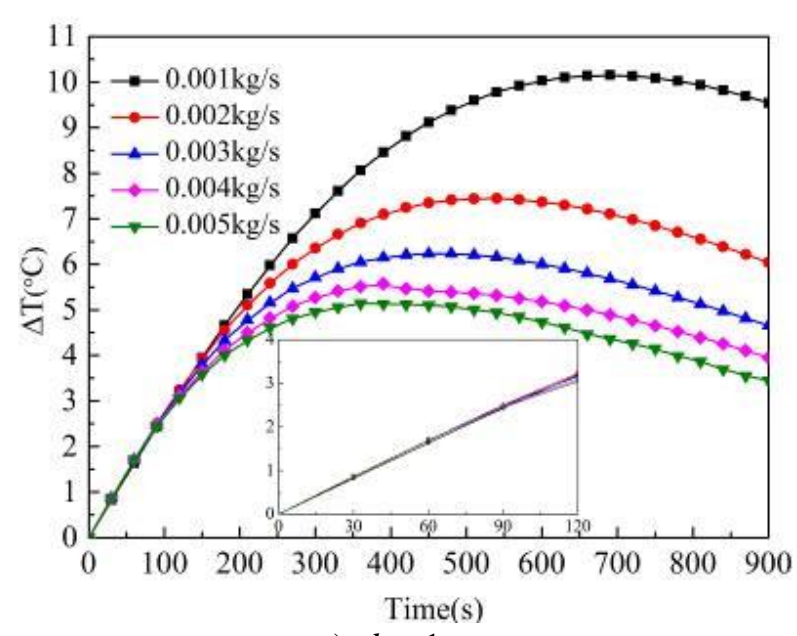

a) $d_{1}=1 \mathrm{~mm}$

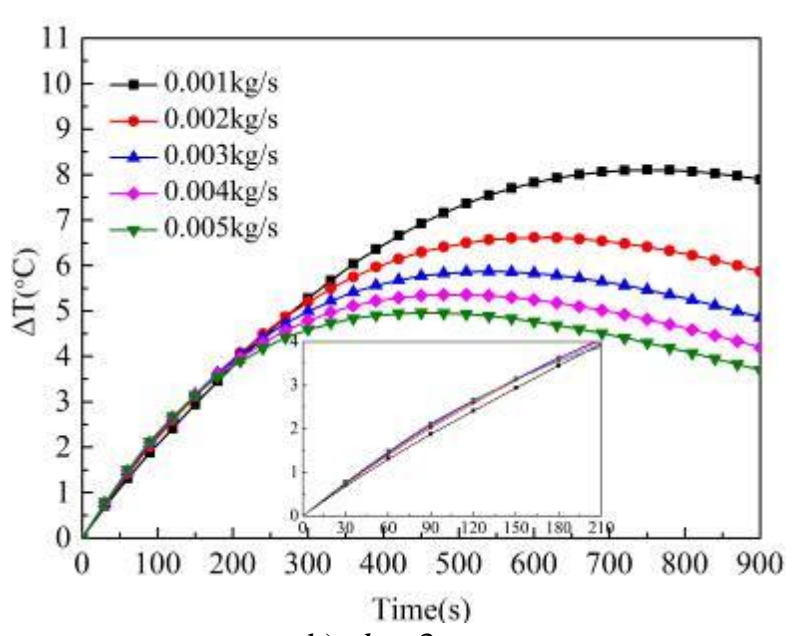

b) $d_{1}=3 \mathrm{~mm}$

Figure 7: Comparison of cells' temperature difference under different $d_{1}$ values and mass flow rates.

\subsection{Effects of mini-channel cross-sectional width on maximum temperature}

Fig. 8 shows that the effects of $d_{1}$ on the cell's maximum temperature are less than the effects of the coolant mass flow rate. Similarly, the change in the maximum temperature under different $d_{1}$ is consistent with the heating curve of the cell. Fig. 8 a indicates that the maximum temperature gradually decreases with increasing $d_{1}$ under a mass flow rate of $0.001 \mathrm{~kg} / \mathrm{s}$. At the same time point, for every $0.5 \mathrm{~mm}$ increase in $d_{1}$, the amount of temperature drop is highly similar. As shown in Fig. 8, at the same mass flow rate, the time at which the highest value of maximum temperature occurs is delayed as $d_{1}$ increases; the maximum temperature curves for two different $d_{1}$ values intersect at a certain point at time $t_{\text {int }}$. Given the small increment in $d_{1}$, the intersection points of each two maximum temperatures are near each other, forming a time interval. At $t_{\text {int }}$, the maximum temperatures of two different $d_{1}$ value models are equal, so the maximum temperatures before and after $t_{\text {int }}$ are in reverse order. Figs. $8 \mathrm{~b}$ and $8 \mathrm{c}$ show that the time interval gradually advances as the mass flow rate increases. The volume of the mini-channel increases with $d_{1}$; when the mass flow rate is constant, the flow velocity of the coolant in the mini-channel decreases, which is not conducive to heat emission. Meanwhile, the interface between the coolant and cold plate increases with $d_{1}$, and the heat transferred from the cell to the coolant increases. In addition, the heating power of the cell gradually reduces.

Fig. 8 shows that the curve of the maximum temperature is an "inverted U-shape" under the combined effects of the abovementioned factors. In other words, the maximum temperature of the cooling system model rises and drops rapidly, whereas the maximum temperature of the cooling system model rises and drops slowly. Under the comprehensive effect of flow velocity and interface, the order of the maximum temperature curves' intersection at time $t_{\mathrm{a}, \mathrm{b}}$ is different under different mass flow rates and different $d_{1}$ values. Thus, when the mass flow rate is $0.002 \mathrm{~kg} / \mathrm{s}$, time $t_{1,2.5}$ that is the maximum temperature curve intersection under $d_{1}=1 \mathrm{~mm}$ and $d_{1}=2.5 \mathrm{~mm}$ is earlier than the time $t_{1.5,2.5}$ that is the maximum temperature curve intersection under $d_{1}=1.5 \mathrm{~mm}$ and $d_{1}=2.5 \mathrm{~mm}$. When the mass flow rate is $0.003 \mathrm{~kg} / \mathrm{s}$, time $t_{1,2.5}$ is later than time $t_{1.5,2.5}$.

Fig. 8 also shows that the effects of $d_{1}$ on the maximum temperature are reduced before the intersection of the curves with the increase in the mass flow rate. Moreover, the slopes of the different maximum temperature curves are the same. The effects on the maximum temperature of $d_{1}$ gradually increase after the intersection of the curves. As $d_{1}$ decreases, the reduction in the maximum temperature is increased. 


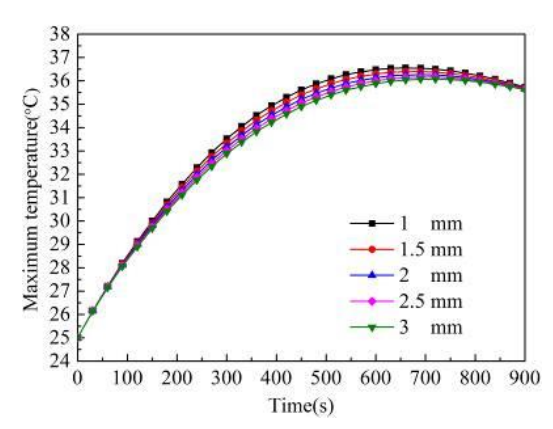

a) $0.001 \mathrm{~kg} / \mathrm{s}$

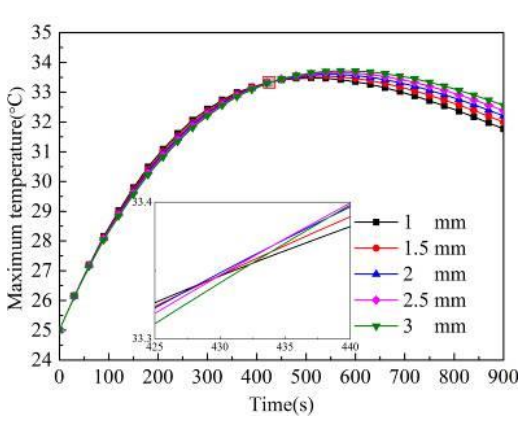

b) $0.002 \mathrm{~kg} / \mathrm{s}$

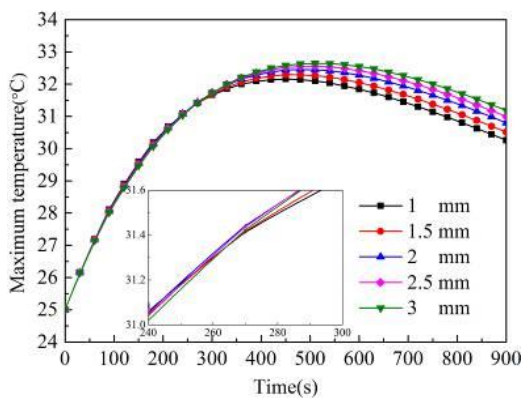

c) $0.003 \mathrm{~kg} / \mathrm{s}$

Figure 8: Comparison of the cells' maximum temperature under different mass flow rates and $d_{1}$ values.

\subsection{Effects of mini-channel cross-sectional width on temperature difference}

As shown in Fig. 9, as $d_{1}$ increases, the time points at which the maximum temperature differences occur are delayed under the same coolant mass flow rate. The temperature difference curves of different $d_{1}$ values intersect. This time interval gradually advances as the mass flow rate increases. This result is consistent with the regulation of the maximum temperature curve. The side $\left(S_{1}\right)$ of the mini-channel's inner surface that is perpendicular to the interface of the cold plate and cell increases with $d_{1}$, whereas the side face $\left(S_{2}\right)$ of the mini-channel's inner surface is parallel to the interface of the cold plate and cell. The increase in $S_{1}$ has a smaller influence on heat conduction than that in $S_{2}$. Fig. 9 a shows that the mass flow rate is $0.001 \mathrm{~kg} / \mathrm{s}$ and the maximum temperature difference is $10.2{ }^{\circ} \mathrm{C}$ when $d_{1}$ is $1 \mathrm{~mm}$. By contrast, the maximum temperature difference is $9.6{ }^{\circ} \mathrm{C}$ when $d_{1}$ is $1.5 \mathrm{~mm}$, leading to a reduction of $0.6^{\circ} \mathrm{C}$. The maximum temperature difference is $8.5^{\circ} \mathrm{C}$ when $d_{1}$ is $2.5 \mathrm{~mm}$. Moreover, the maximum temperature difference is $8.1^{\circ} \mathrm{C}$ when $d_{1}$ is $3 \mathrm{~mm}$, so the reduction is $0.4{ }^{\circ} \mathrm{C}$. Under the same mass flow rate, the temperature difference reduction gradually decreases with increasing $d_{1}$. Although the $d_{1}$ values are different, the mass flow rates in the mini-channel are small. Thus, the flow velocity variation is also relatively small. Under low mass flow rates, good heat conduction has advantages. Increment of $d_{1}$ increases the contact area between the coolant and cold plate and enhances heat transfer. The $d_{1}$ value changes from $1 \mathrm{~mm}$ to $3 \mathrm{~mm}$; although the temperature difference is reduced by approximately $2.1^{\circ} \mathrm{C}$, the volume of the entire cold plate is doubled. As Figs. $9 \mathrm{~b}$ and $9 \mathrm{c}$ show, under the same mass flow rate and before the temperature difference curves intersect, the interval between the temperature difference curve with $d_{1}$ of $2 \mathrm{~mm}$ and the temperature difference curve with $d_{1}$ of $2.5 \mathrm{~mm}$ is the largest. Therefore, the reduction in temperature difference is the greatest when $d_{1}$ increases from $2 \mathrm{~mm}$ to $2.5 \mathrm{~mm}$. This result reveals that the economical value of $d_{1}$ can be obtained in the cooling of cells. The temperature difference curves have longer intersecting time intervals than the time intervals where the maximum temperature curves intersect, which is related to the following factors. On the one hand, the interface of the coolant and cold plate increases with $d_{1}$. Reducing the temperature difference is beneficial. Meanwhile, the flow velocity of the coolant in the mini-channel is reduced, which is not conducive to reducing the temperature difference. On the other hand, the heating power of the cell gradually decreases with time, which affects the temperature difference with time. At a specific time interval, the temperature difference curve with $d_{1}$ of $2 \mathrm{~mm}$ is over other temperature difference curves under the same mass flow rate in the latter half discharge time. As the mass flow rate increases, this time interval not only advances in time but also increases in duration. Therefore, the cooling capacity of the cooling system with $d_{1}$ of $2 \mathrm{~mm}$ is lower than those of other cooling systems. $S_{1}$ with $d_{1}$ of $2 \mathrm{~mm}$ is smaller than $S_{1}$ with $d_{1}$ of 2.5 and 
$3 \mathrm{~mm}$. The flow velocity of the coolant in the mini-channel is lower than that of the minichannel with $d_{1}$ values of 1 and $1.5 \mathrm{~mm}$.

Fig. 9 indicates that the temperature difference curves of different $d_{1}$ values are closer to each other with increasing mass flow rate before the time interval of the temperature difference curves intersect. After the time intervals intersect, the temperature difference curves of different $d_{1}$ values are further away from each other.

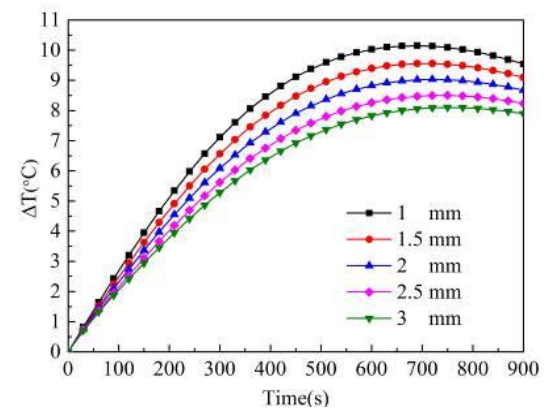

a) $0.001 \mathrm{~kg} / \mathrm{s}$

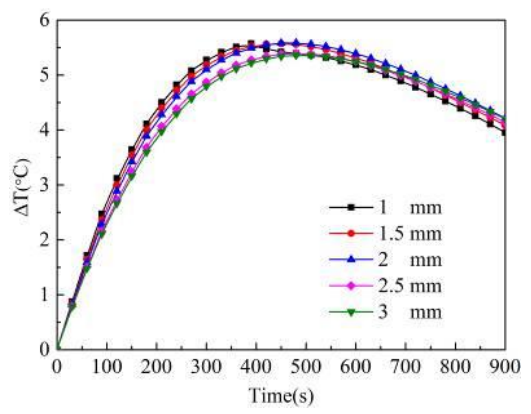

b) $0.004 \mathrm{~kg} / \mathrm{s}$

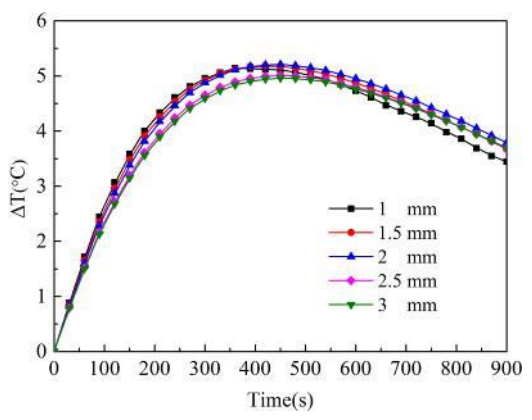

c) $0.005 \mathrm{~kg} / \mathrm{s}$

Figure 9: Comparison of cells' temperature differences under different mass flow rates and $d_{1}$ values.

\subsection{Effects of mass flow rates and mini-channel cross-sectional width on pressure drop}

In this study, we find that many cold plate manufacturers have a conflicting problem, that is, the volume of the cold plate cooling system must be reduced to increase the power density of the battery pack. The best way is to reduce the thickness of the cold plate by reducing the cross-section of the mini-channel. Under the same mass flow rate, the pressure drop of the mini-channel increases. Meanwhile, reducing the thickness of the cold plate can increase the energy consumption of the cooling system.

In Fig. 10, the ordinate $\mathrm{Z}$ represents the average pressure drop of the mini-channel, the abscissa $\mathrm{X}$ represents the mini-channel cross-sectional width $d_{1}$, and the abscissa Y represents the mass flow rate of the coolant.

As shown in Fig. 10, the effects of $d_{1}$ and mass flow rates on the average pressure drop are analysed. The equations are fitted separately.

First, the relationship between the average pressure drop and mass flow rate is obtained under different $d_{1}$ values.

$$
\begin{gathered}
P_{1.0}=2204250 \cdot n-259 \\
P_{1.5}=671116 \cdot n+26 \\
P_{2.0}=365353 \cdot n-116 \\
P_{2.5}=198534 \cdot n-70 \\
P_{3.0}=121494 \cdot n-49
\end{gathered}
$$

where $P_{1.0}, P_{1.5}, P_{2.0}, P_{2.5}$, and $P_{3.0}$ are the average pressure drops of $d_{1}$ for $1,1.5,2,2.5$, and $3 \mathrm{~mm}(\mathrm{~Pa})$, respectively; and $n$ presents the mass flow rate $(\mathrm{kg} / \mathrm{s})$.

Fig. 10 illustrates the linear relationship of the average pressure drop of the mini-channel and the mass flow rate under different values of $d_{1}$. The average pressure drop gradually increases with the mass flow rate. The simulation data are fitted by using a first-order function, and the goodness of fit $\left(R^{2}\right)$ is greater than 0.99. Eqs. (1) to (5) show that the slopes of the curves do not change with the increase in the mass flow rate. Therefore, the increase in the average pressure drop does not change. 


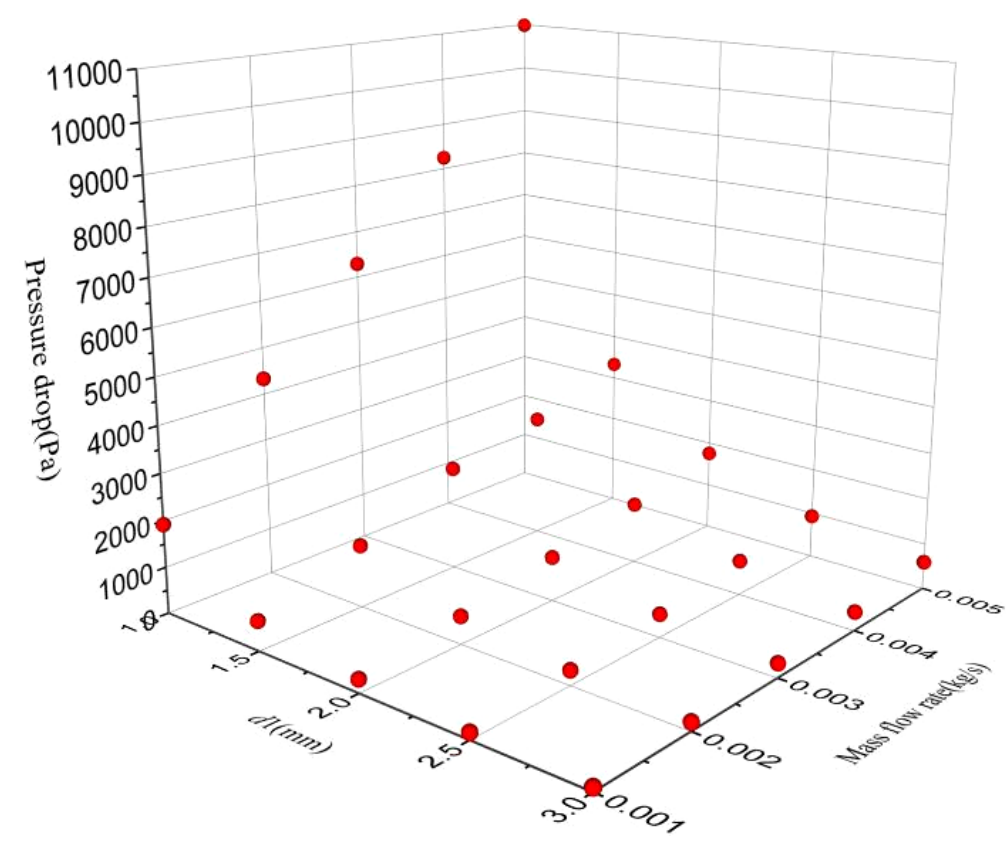

Figure 10: Pressure drop of coolant under different mass flow rates and $d_{1}$ values.

The relationship between the average pressure drop and $d_{1}$ is obtained under the different mass flow rates of the coolant.

$$
\begin{gathered}
P_{0.001}=19674.57 \mathrm{e}^{d / 0.42}+93.85 \\
P_{0.002}=51711.57 \mathrm{e}^{d / 0.40}+205.61 \\
P_{0.003}=54666.62 \mathrm{e}^{d / 0.45}+258.99 \\
P_{0.004}=90147.28 \mathrm{e}^{d / 0.41}+486.73 \\
P_{0.005}=141241.93 \mathrm{e}^{d / 0.38}+715.71
\end{gathered}
$$

where $P_{0.001}, P_{0.002}, P_{0.003}, P_{0.004}$, and $P_{0.005}$ are the average pressure drops of the mass flow rate for $0.001,0.002,0.003,0.004$, and $0.005 \mathrm{~kg} / \mathrm{s}(\mathrm{Pa})$, respectively; and $d$ is the minichannel cross-sectional width $(\mathrm{mm})$.

Fig. 10 indicates the negative index relationship of the average pressure drop of the minichannel and the value of $d_{1}$ under different mass flow rates. The average pressure drop gradually decreases with the increase in $d_{1}$. The simulation data are fitted by using a negative index function. The goodness of fit $R^{2}$ is greater than 0.99. Eqs. (6) to (10) show that the absolute value of the curve's slope decreases with the increase in $d_{1}$, and the reduction in the average pressure drop gradually decreases.

Fig. 10 also shows that the average pressure drop is negatively correlated with $d_{1}$ and positively correlated with the mass flow rate. However, under the combined impact of the two factors, the average pressure drop also shows other regulations. When $d_{1}$ is in the interval range $[1,3]$ and the mass flow rate is in the interval range of [0.001, 0.003], as expressed by Eqs. (1) to (5), the slope of the functional equation gradually decreases with increasing $d_{1}$, and the reduction of the slope gradually decreases. This rule is more significant before the $d_{1}$ value for $2 \mathrm{~mm}$. In Eqs. (6) to (10), the slope of the function equation gradually increases at the same $d_{1}$ value with the increase in the mass flow rate. When the mass flow rate $(n)$ is less than $0.003 \mathrm{~kg} / \mathrm{s}$, this regulation is evident. 


\section{CONCLUSION}

To improve the practicability of cold plate in the battery thermal management system, a finite element model of the cold plate cooling system was established. Twenty-five numerical calculations were performed by changing the cross-sectional width $\left(d_{1}\right)$ of the mini-channel in the cold plate and the mass flow rate of the coolant at the mini-channel inlet. The curves of the maximum temperature, temperature difference, and pressure drop of the mini-channel were obtained. The following conclusions were drawn.

(1) The increase in the mass flow rate can reduce the maximum temperature and maximum temperature difference of cells. However, the larger the mass flow rate is, the earlier the highest value of maximum temperature and the maximum temperature difference of the cell appear in the corresponding cooling system. In addition, the mass flow rate of the coolant increases with the gradual decrease in the reduction of the maximum temperature and maximum temperature difference. Although increasing the mass flow rate of the coolant can greatly reduce the maximum temperature and maximum temperature difference of cells, the economy worsens with the increase in the mass flow rate.

(2) The temperature trend over time presents a typical inverted U-shape with the change in the mini-channel cross-sectional width. At the same mass flow rate, the maximum temperature and temperature difference curves under different $d_{1}$ values have a time interval in which the curves intersect. Before time interval, the values of $d_{1}$ exert minimal effects on the maximum temperature but greater effects on the temperature difference. The duration of the high rate discharge of the cell varies due to different electric vehicles, and the selection of an appropriate $d_{1}$ value can effectively dissipate heat and reduce the volume of the cooling system.

(3) The relationship of the mass flow rate and pressure drop is a positive first-order function, whereas the relationship of the mini-channel cross-sectional width and pressure drop is a negative exponential function. The effects of the mass flow rate on the average pressure drop decrease as $d_{1}$ increases. To reduce the energy consumption of the cooling system and meet the cold plate strength requirement, an appropriate mini-channel cross-sectional width must be selected when the mass flow rate is large.

To achieve a useful and practical cooling method, the mini-channel cold plate cooling system must be efficient and economical. In this study, the effects of the increase in the inlet mass flow rate and mini-channel cross-sectional width on the battery temperature reduction were analysed, and the relationships between inlet mass flow rate and cold plate pressure drop and between the mini-channel cross-sectional width and cold plate pressure drop were obtained. This study provides guidance for the design of the cold plate cooling system. In future research, many experiments are required to obtain actual data to verify the effects of the mass flow rate and mini-channel cross-sectional width on the temperature of lithium-ion batteries and pressure drop of the mini-channel cold plate. Additional factors should be analysed to confirm their effects on the cooling of batteries and the pressure drop of the cold plate.

\section{ACKNOWLEDGEMENT}

This work was supported by the National Key Research and Development Program of China (Grant No. 2016YFD0701005), National Natural Science Foundation of China (Grant No. 51674155), Innovative Team Development Project of Ministry of Education (Grant No. IRT_16R45), Science and Technology Major Project of Shandong Province (Grant No. 2015ZDXX0601C01) and Special funds for Climbing Project of Taishan Scholars. 


\section{REFERENCES}

[1] Hannan, M. A.; Lipu, M. S. H.; Hussain, A.; Mohamed, A. (2017). A review of lithium-ion battery state of charge estimation and management system in electric vehicle applications: challenges and recommendations, Renewable and Sustainable Energy Reviews, Vol. 78, 834-854, doi:10.1016/j.rser.2017.05.001

[2] Liu, S.; Gong, D. (2014). Modelling and simulation on recycling of electric vehicle batteries using agent approach, International Journal of Simulation Modelling, Vol. 13, No. 1, 79-92, doi:10.2507/IJSIMM13(1)CO1

[3] Lai, Y.-Q.; Du, S.-L.; Ai, L.; Ai, L.-H.; Cheng, Y.; Tang, Y.-W.; Jia, M. (2015). Insight into heat generation of lithium ion batteries based on the electrochemical-thermal model at high discharge rates, International Journal of Hydrogen Energy, Vol. 40, No. 38, 13039-13049, doi:10.1016/j.ijhydene.2015.07.079

[4] Cho, G. Y.; Choi, J. W.; Park, J. H.; Cha, S. W. (2014). Transient modeling and validation of lithium ion battery pack with air cooled thermal management system for electric vehicles, International Journal of Automotive Technology, Vol. 15, No. 5, 795-803, doi:10.1007/s12239$\underline{014-0083-\mathrm{x}}$

[5] Situ, W.-F.; Zhang, G.-Q.; Li, X.-X.; Yang, X.-Q.; Wei, C.; Rao, M.-M.; Wang, Z.-Y.; Wang, C.; Wu, W.-X. (2017). A thermal management system for rectangular $\mathrm{LiFePO}_{4}$ battery module using novel double copper mesh-enhanced phase change material plates, Energy, Vol. 141, 613-623, doi:10.1016/j.energy.2017.09.083

[6] Saw, L. H.; Yew, M. C.; Yew, M. K.; Chong, W. T. (2017). Numerical analyses on aluminum foams cooling plate for lithium-ion batteries, Energy Procedia, Vol. 105, 4751-4756, doi:10.1016/j.egypro.2017.03.1034

[7] Bunch, D. S.; Bradley, M.; Golob, T. F.; Kitamura, R.; Occhiuzzo, G. P. (1993). Demand for clean-fuel vehicles in California: A discrete-choice stated preference pilot project, Transportation Research, Part A: Policy and Practice, Vol. 27, No. 3, 237-253, doi:10.1016/09658564(93)90062-P

[8] Lu, Z.; Meng, X. Z.; Wei, L. C.; Hu, W. Y.; Zhang, L. Y.; Jin, L. W. (2016). Thermal management of densely-packed EV battery with forced air cooling strategies, Energy Procedia, Vol. 88, 682-688, doi:10.1016/j.egypro.2016.06.098

[9] Zou, D.-Q.; Ma, X.-F.; Liu, X.-S.; Zheng, P.-J.; Hu, Y.-P. (2018). Thermal performance enhancement of composite phase change materials (PCM) using graphene and carbon nanotubes as additives for the potential application in lithium-ion power battery, International Journal of Heat and Mass Transfer, Vol. 120, 33-41, doi:10.1016/j.ijheatmasstransfer.2017.12.024

[10] Greco, A.; Cao, D.-P.; Jiang, X.; Yang, H. (2014). A theoretical and computational study of lithium-ion battery thermal management for electric vehicles using heat pipes, Journal of Power Sources, Vol. 257, 344-355, doi:10.1016/j.jpowsour.2014.02.004

[11] Rao, Z.-H.; Huo, Y.-T.; Liu, X.-J. (2014). Experimental study of an OHP-cooled thermal management system for electric vehicle power battery, Experimental Thermal and Fluid Science, Vol. 57, 20-26, doi:10.1016/j.expthermflusci.2014.03.017

[12] Wang, C.; Zhang, G.-Q.; Meng, L.-K.; Li, X.-X.; Situ, W.-F.; Lv, Y.-F.; Rao, M.-M. (2017). Liquid cooling based on thermal silica plate for battery thermal management system, International Journal of Energy Research, Vol. 41, No. 15, 2468-2479, doi:10.1002/er.3801

[13] Chen, D.-F.; Jiang, J.-C.; Kim, G.-H.; Yang, C.-B.; Pesaran, A. (2016). Comparison of different cooling methods for lithium ion battery cells, Applied Thermal Engineering, Vol. 94, 846-854, doi:10.1016/j.applthermaleng.2015.10.015

[14] Qian, Z.; Li, Y.-M.; Rao, Z.-H. (2016). Thermal performance of lithium-ion battery thermal management system by using mini-channel cooling, Energy Conversion and Management, Vol. 126, 622-631, doi:10.1016/j.enconman.2016.08.063

[15] Jarrett, A.; Kim, I. Y. (2014). Influence of operating conditions on the optimum design of electric vehicle battery cooling plates, Journal of Power Sources, Vol. 245, 644-655, doi:10.1016/ j.jpowsour.2013.06.114

[16] Panchal, S.; Khasow, R.; Dincer, I.; Agelin-Chaab, M.; Fraser, R.; Fowler, M. (2017). Numerical modeling and experimental investigation of a prismatic battery subjected to water cooling, 
Numerical Heat Transfer, Part A: Applications, Vol. 71, No. 6, 626-637, doi: $10.1080 / 10407782.2016 .1277938$

[17] Panchal, S.; Khasow, R.; Dincer, I.; Agelin-Chaab, M.; Fraser, R.; Fowler, M. (2017). Thermal design and simulation of mini-channel cold plate for water cooled large sized prismatic lithiumion battery, Applied Thermal Engineering, Vol. 122, 80-90, doi:10.1016/ j.applthermaleng.2017.05.010

[18] Huo, Y.-T.; Rao, Z.-H.; Liu, X.-J.; Zhao, J.-T. (2015). Investigation of power battery thermal management by using mini-channel cold plate, Energy Conversion and Management, Vol. 89, 387-395, doi:10.1016/j.enconman.2014.10.015

[19] Jin, L. W.; Lee, P. S.; Kong, X. X.; Fan, Y.; Chou, S. K. (2014). Ultra-thin minichannel LCP for EV battery thermal management, Applied Energy, Vol. 113, 1786-1794, doi:10.1016/ j.apenergy.2013.07.013

[20] Bernardi, D.; Pawlikowski, E.; Newman, J. (1985). A general energy balance for battery systems, Journal of the Electrochemical Society, Vol. 132, No. 1, 5-12, doi:10.1149/1.2113792 